Vol. 5, No. 3-4, 2019

Andriy Trostianchyn ${ }^{1}$, Serhii Shvachko ${ }^{2}$, Volodymyr Kulyk ${ }^{3}$, Eduard Pleshakov $^{4}$, Yuriy Molkov ${ }^{5}$, Taras Lenkovskiy ${ }^{6}$

1. Department of Applied Materials Science and Materials Engineering, Lviv Polytechnic National University,

Ukraine, Lviv, S. Bandery street 12, E-mail: andrii.m.trostianchyn@lpnu.ua

2. Department of Applied Materials Science and Materials Engineering, Lviv Polytechnic National University, Ukraine, Lviv, S. Bandery street 12, E-mail: serhii.h.shvachko@lpnu.ua

3. Department of Applied Materials Science and Materials Engineering, Lviv Polytechnic National University, Ukraine, Lviv, S. Bandery street 12, E-mail: volodymyr.v.kulyk@lpnu.ua

4. Department of Applied Materials Science and Materials Engineering, Lviv Polytechnic National University, Ukraine, Lviv, S. Bandery street 12, E-mail: eduard.i.pleshakov@lpnu.ua 5. Department of Strength and Durability of Structures under Complex Loading, Karpenko Physico-mechanical Institute of the NAS of Ukraine, Ukraine, Lviv, Naukova street 5, E-mail: molkov@ipm.lviv.ua 6. Department of Strength and Durability of Structures under Complex Loading, Karpenko Physico-mechanical Institute of the NAS of Ukraine, Ukraine, Lviv, Naukova street 5, E-mail: lenkovskiy@ipm.lviv.ua

\title{
MICROSTRUCTURE AND MICROHARDNESS OF NICKEL-BASE HEAT-RESISTANT ALLOYS OBTAINED BY DIRECTIONAL AND EQUILIBRIUM CRYSTALLIZATION
}

Received: August 22, 2019 / Revised: September 28, 2019 / Accepted: December 28, 2019

(C) Trostianchyn A., Shvachko S., Kulyk V., Pleshakov E., Molkov Yu., Lenkovskiy T., 2019

\begin{abstract}
In order to determine the safe operational life of the components of gas turbine engines (GTE), introductory tests of nickel-base heat-resistant alloys (NHRA) have been performed. $\mathrm{X}$-ray fluorescence and X-ray diffraction analyzes, optical microscopy and Vickers hardness measurements provided data on the phase-structural state and mechanical properties of the pristine ZhS6K-VI and ZhS32-VI alloys obtained by equilibrium and high-speed directional crystallization, respectively. Almost complete compliance of the investigated materials with the certified alloys in chemical and phase composition has been found. A significant difference in the parameters of the fragments of the microstructure of the investigated alloys, which is naturally consistent with the conditions of equilibrium and high-speed directional crystallizations, was revealed. A slightly lower anisotropy of microhardness $(2.8 \%)$, measured in transverse and longitudinal sections, was found in the ZhS6K-VI alloy as compared to the anisotropy (5.1\%) in the ZhS32-VI alloy. The obtained results will be used to test a non-destructive method for determining the safe operational life of gas turbine engine components.
\end{abstract}

Keywords: heat-resistant alloys, nickel-base superalloys, directional crystallization, equilibrium crystallization, gas turbine, blade, microstructure, microhardness.

\section{Introduction and problem statement}

An important task for the safe operation of the components of gas turbine engines (GTE) is to develop a non-destructive method for determining their operational life. A technique [1] for determining the fracture energy density of material is proposed, which is based on determining the specific fracture energy of material and provides the estimation of local deformation of stress zones of metal parts of machines and structural elements by modern optical-digital means. This makes it possible to determine the ratio of the residual deformation energy of the material in operation to the fracture energy of the material in the as-received state, calculate the defect density of the material and estimate the residual operational life of turbine engine parts. To implement this approach, it is necessary to have data on the initial structure and mechanical properties of the materials in the as-received state used to manufacture the components of a GTE. In particular, cast nickel-base heat-resistant alloys (NHRA) are widely used to manufacture gas 
turbine engine blades. Analysis of literature sources [2]-[8] shows that the structure and operational properties of these alloys are determined by the chemical composition, production conditions, and thermomechanical treatment.

In terms of chemical composition, NHRA contains the largest number of alloying elements, the quantitative ratio of which provides the maximum ability to precipitation hardening. They are hardened due to the precipitation of coherent dispersed $(\leq 0.5 \mu \mathrm{m})$ cubic $\gamma^{\prime}$-phase particles based on the $\mathrm{Ni}_{3} \mathrm{Al}$ intermetallic, which is formed due to the decomposition of the supersaturated $\gamma$-phase during cooling to a temperature below the $\gamma^{\prime}$ solvus. Both phase components have isomorphic crystal lattices (FCC structure), with the only difference that the $\gamma$-phase is a nickel-based disordered substitutional solid solution with a lattice period that differs slightly (up to $0.3 \%$ ) from the ordered $\gamma^{\prime}$-phase period. Along with the hardening by $\gamma^{\prime}$-phase particles, precipitation hardening by carbides and borides of various types, the total amount of which reaches $1.5-2 \mathrm{vol} \%$, is implemented in NHRA. Thus, NHRA consists of a nickel-base high-alloyed $\gamma$-solid solution, intermetallic $\gamma^{\prime}$-phase, monocarbides of $\mathrm{MC}$ type $(\mathrm{M}=\mathrm{Ti}, \mathrm{Ta}, \mathrm{Nb})$, and borides of different types [2], [3]. The volume fraction of $\gamma^{\prime}$-phase particles in the alloys reaches $60-70 \%$. In an NHRA of eutectic type with natural composite structure of $\gamma / \gamma^{\prime}-\mathrm{MC}$ type $(\mathrm{M}=\mathrm{Nb}, \mathrm{Ta})$, hardening by carbides is crucial: MC-carbides shaped like continuous fibers formed by directional crystallization with a flat growth front, cause at high temperatures hardening by composite mechanism [4].

The example of the ZhS32-VI alloy shows [5] that the parameters of crystal lattices of $\gamma$ and $\gamma^{\prime}$ phases, their dimensional mismatch and volume content, as well as the presence of texture, are determined by production technologies: single-crystal casting, gas atomization, selective laser sintering. According to the work [6], the temperature gradient during the directional crystallization of the ZhS32-VI alloy affects the formation of a single-crystal or polycrystalline structure, the deviation from a given crystallographic orientation [11], as well as microstructure parameters (the distance between the axes of first- and secondorder dendrites, sizes of dendritic cells and structural components, the morphology of carbides, etc.). The influence of modification by dispersed titanium carbide on the structure and properties of the ZhS6K alloy is shown in the work [7], while the possibility of using hot isostatic pressing to reduce the microporosity of the safety-critical castings from the ZhS6K-VI and ZhS32-VI alloys is analyzed in the work [8]. Data of the work [9] indicate a significant effect of microstructure on the mechanical properties of nickel-base heat-resistant alloys.

Given that the method of determining the safe operational life of GTE components should be equally suitable for the usage regardless of manufacturing technologies and features of their microstructure, introductory (before applying the technique [1]) studies of the microstructure and microhardness of the $\mathrm{ZhS32-VI} \mathrm{and} \mathrm{ZhS6K-VI} \mathrm{alloys} \mathrm{obtained} \mathrm{by} \mathrm{directional} \mathrm{and} \mathrm{equilibrium} \mathrm{crystallizations} \mathrm{have} \mathrm{been}$ performed in this work.

\section{Samples, technique, and equipment}

Samples of the ZhS6K-VI alloy after equilibrium crystallization with polycrystalline structure and the ZhS32-VI alloy after high-speed directional crystallization with the single-crystal structure were provided for research by the Zaporizhzhia Polytechnic National University in the form of cylindrical rods with a diameter of $15 \mathrm{~mm}$ and a length of $150 \mathrm{~mm}$. After smelting, the samples were subjected to homogenization annealing in vacuum according to the standard modes: the ZhS6K-VI alloy at a temperature of $1210{ }^{\circ} \mathrm{C}$ for $2 \mathrm{~h}$, and the $\mathrm{ZhS32-VI}$ alloy at $1270{ }^{\circ} \mathrm{C}$ for $1 \mathrm{~h} 15 \mathrm{~min}$.

The chemical composition (excluding the content of light elements from ${ }_{1} \mathrm{H}$ to ${ }_{11} \mathrm{Na}$ ) was determined by X-ray fluorescence analysis using an X-ray energy spectrometer CEP-01 "ElvaxLight". The weight ratio of the detected elements was calculated using ElvaX 4.4 software [10].

$\mathrm{X}$-ray diffraction analysis of alloys was based on diffraction patterns obtained on a diffractometer DRON-4.0M ( $\mathrm{Cu} K_{\alpha}$ irradiation). For X-ray data arrays, the profile and structural parameters of all present phases were refined by the Rietveld method using the WinCSD [11], PowderCell [12], and FullProfSuite [13] software packages.

The microstructure of the alloys was examined on the transverse surfaces of the samples cut along and across the longitudinal axis of the samples using an optical microscope MMT-14S at magnifications from 100 to 500 times. For chemical contrast, a reagent of a mixture of concentrated nitric and 


\section{Microstructure and Microhardness of Nickel-base Heat-resistant Alloys Obtained by ...}

hydrochloric acids was used with a ratio of 1:3 by volume, respectively. Documentation of the microstructure was performed using an eyepiece camera LCMOS14000KPA.

The microhardness of the samples was measured by the Vickers method according to DSTU ISO 6507-1:2007 [14] on a microhardness tester NOVOTEST TS-MKV1 under a load of $0.98 \mathrm{~N}$ applied with a diamond indenter in the shape of a regular pyramid.

\section{Results and discussion}

The results of determining the chemical composition of the test samples are presented in Table 1. It should be noted that since the content of light elements (up to $\mathrm{Na}$ ) was not determined, the results reflect the relative relationship between the detected elements. By the requirements of TD norms [8], the carbon content in these alloys is in the range of $0.12-0.20 \mathrm{wt} \%$, and a comparative analysis of the content of the detected elements indicates almost complete compliance of the investigated materials with the certified alloys in chemical composition.

Table 1

Chemical composition of the investigated alloys

\begin{tabular}{|c|c|c|c|c|c|c|c|c|c|c|c|c|}
\hline \multirow{2}{*}{$\begin{array}{l}\text { Alloy } \\
\text { brand }\end{array}$} & \multicolumn{12}{|c|}{ Content of elements, wt $\%$} \\
\hline & $\mathrm{Ni}$ & $\mathrm{Cr}$ & Co & W & $\mathrm{Al}$ & $\mathrm{Ti}$ & Mo & $\mathrm{Nb}$ & $\mathrm{Ta}$ & $\operatorname{Re}$ & $\mathrm{Fe}$ & $\mathrm{Si}$ \\
\hline ZhS6K-VI & 67.2 & 10.0 & 4.6 & 5.3 & 5.1 & 3.1 & 4.3 & - & - & - & 0.1 & 0.3 \\
\hline TD norms & basis & $\begin{array}{l}9.5- \\
12.0\end{array}$ & $\begin{array}{c}4.0- \\
5.5\end{array}$ & $\begin{array}{c}4.5- \\
5.5\end{array}$ & $\begin{array}{c}5.0- \\
6.0\end{array}$ & $\begin{array}{c}2.5- \\
3.2 \\
\end{array}$ & $\begin{array}{c}3.5- \\
4.5\end{array}$ & - & - & - & $\leq 2.0$ & $\leq 0.4$ \\
\hline ZhS32-VI & 60.7 & 4.6 & 9.1 & 8.6 & 6.1 & - & 1.3 & 1.6 & 4,2 & 3.6 & 0.2 & - \\
\hline TD norms & basis & $\begin{array}{c}4.5- \\
5.5\end{array}$ & $\begin{array}{c}9.0- \\
9.5\end{array}$ & $\begin{array}{c}8.1- \\
8.9\end{array}$ & $\begin{array}{c}5.7- \\
6.2\end{array}$ & - & $\begin{array}{c}0.9- \\
1.3\end{array}$ & $\begin{array}{l}1.4- \\
1.8\end{array}$ & $\begin{array}{c}3.7- \\
4.3\end{array}$ & $\begin{array}{c}3.6- \\
4.3\end{array}$ & $\leq 0.5$ & $\leq 0.3$ \\
\hline
\end{tabular}

According to the results of X-ray analysis of the investigated alloys (Fig. 1), it was found that the main phase is the binary compound $\mathrm{Ni}_{3} \mathrm{Al}$, which belongs to the $\mathrm{Fe}_{3} \mathrm{C}$ structural type (spatial group Pnma, Pearson symbol $o P 16$ ). Also, a small number of unidentified phases were found. By comparing the reflex intensities of the obtained diffraction patterns with the theoretical diffraction pattern for the $\mathrm{Ni}_{3} \mathrm{Al}$ compound, it was concluded that the predominant grain orientation (texture) for both samples was along the crystallographic direction [10]. Analysis of the relative intensities of the peaks at $2 \theta \approx 25^{\circ}(h k l$ index (100)) indicates that the ZhS32-VI alloy has a predominant orientation one and a half times greater than the ZhS6K-VI alloy (ZhS32-VI $\approx 75$ a.u., ZhS6K-VI $\approx 47$ a.u.).

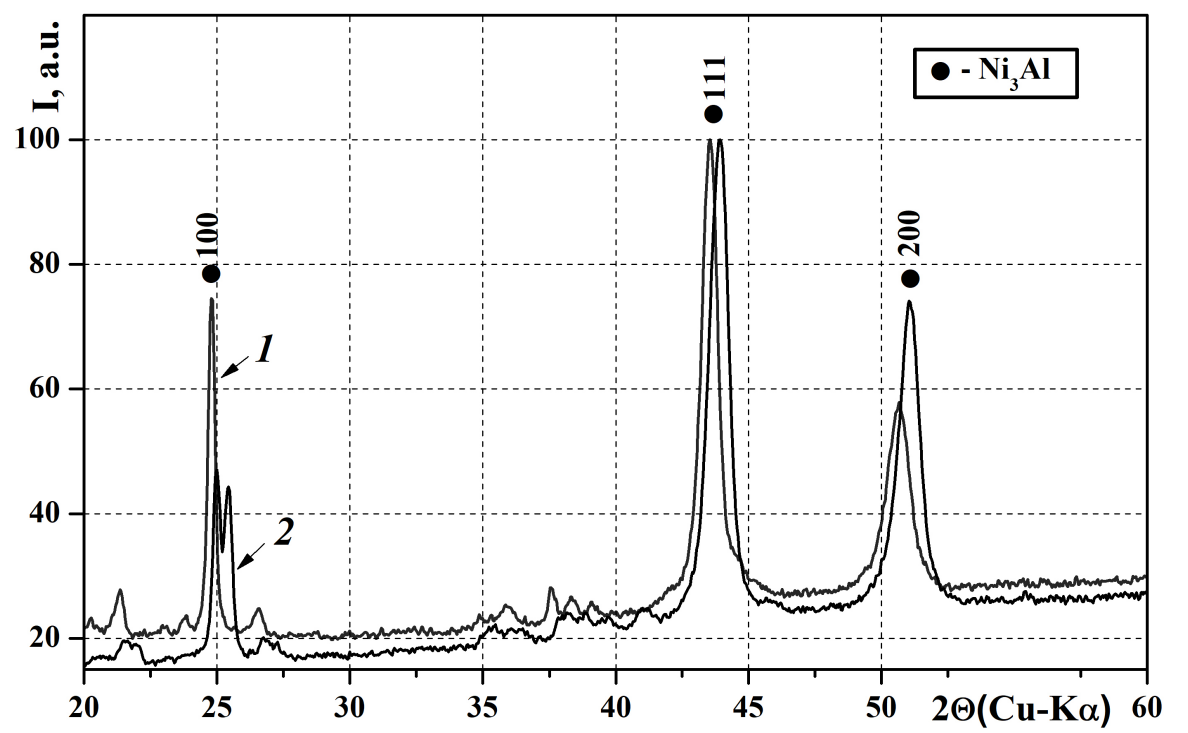

Fig. 1. Diffraction patterns for the ZhS32-VI (curve 1) and ZhS6K-VI (curve 2) alloys

The microhardness of samples of the ZhS32-VI and ZhS6K-VI alloys was measured in mutually perpendicular directions relative to the longitudinal axis. The results are presented in Table 2. 
Andriy Trostianchyn, Serhii Shvachko, Volodymyr Kulyk, Eduard Pleshakov, Yuriy Molkov, et al.

Table 2

Microhardness of the tested samples

\begin{tabular}{|c|c|c|c|c|}
\hline \multirow{2}{*}{$\begin{array}{c}\text { No. of } \\
\text { measurement }\end{array}$} & \multicolumn{2}{|c|}{ ZhS32-VI alloy } & \multicolumn{2}{c|}{ ZhS6K-VI alloy } \\
\cline { 2 - 5 } & $\begin{array}{c}\text { Longitudinal } \\
\text { direction, HV }\end{array}$ & $\begin{array}{c}\text { Transverse } \\
\text { direction, HV }\end{array}$ & $\begin{array}{c}\text { Longitudinal } \\
\text { direction, HV }\end{array}$ & $\begin{array}{c}\text { Transverse } \\
\text { direction, HV }\end{array}$ \\
\hline 1 & 548.8 & 588.1 & 613 & 564.1 \\
\hline 2 & 556.4 & 579.1 & 588.1 & 579.9 \\
\hline 3 & 556.4 & 587.2 & 548.8 & 556.4 \\
\hline Average value, HV & 553.9 & 583.6 & 583.3 & 566.8 \\
\hline
\end{tabular}

The obtained results indicate an insignificant difference in the values of microhardness measured in the longitudinal and transverse directions. In particular, for the ZhS32-VI alloy obtained by directional crystallization, the microhardness is higher in the transverse direction, while for the ZhS6K-VI alloy obtained by equilibrium crystallization - vice versa. Besides, the difference in the values of microhardness in the latter alloy is lower and is $2.8 \%$ compared to $5.1 \%$ for the $\mathrm{ZhS} 32$-VI alloy.

Optical microscopy revealed that the ZhS32-VI alloy has a typical structure (Fig. 2), characteristic of alloys of directional crystallization. It consists of a nickel-based $\gamma$-solid solution, nanosized particles of the reinforcing $\gamma^{\prime}$-phase based on $\mathrm{Ni}_{3}(\mathrm{Ti}, \mathrm{Al}),\left(\gamma+\gamma^{\prime}\right)$ eutectic, and fine-dispersed carbide phases [15].

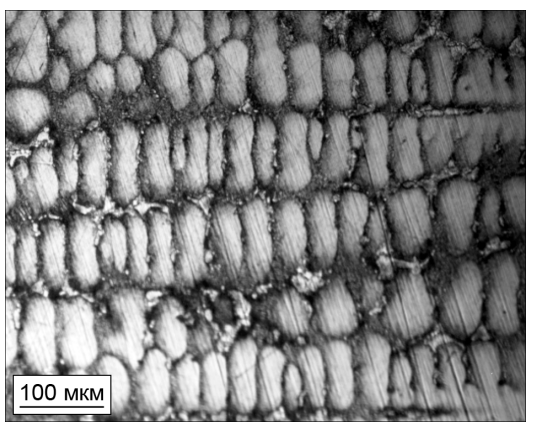

a

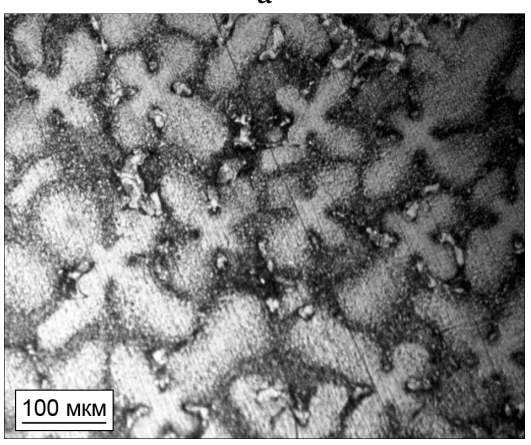

d

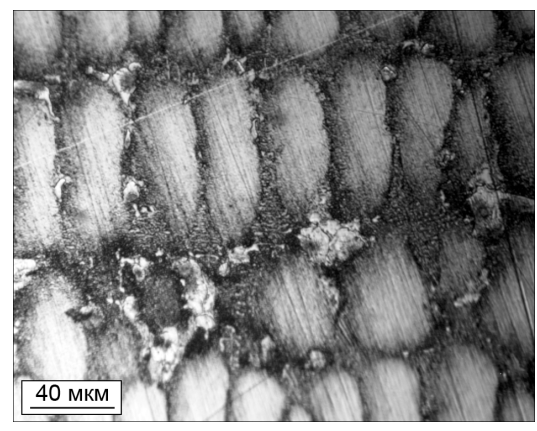

b

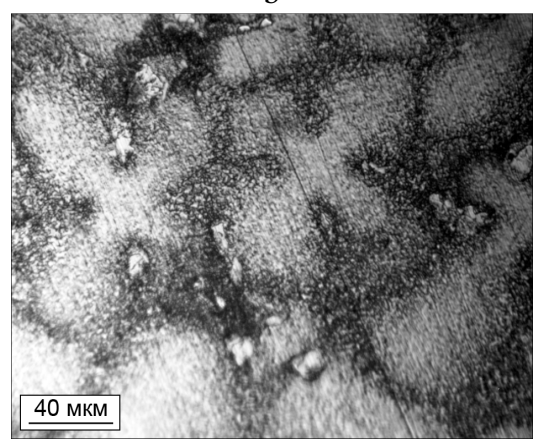

e

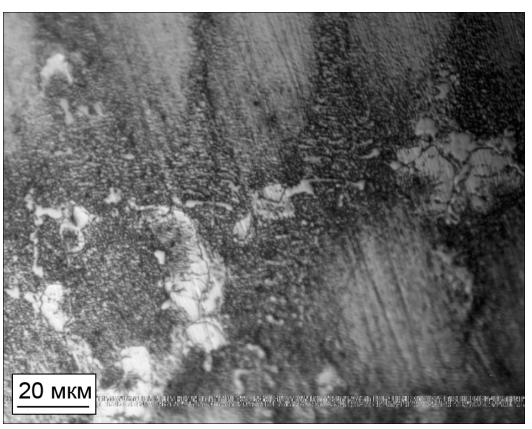

c

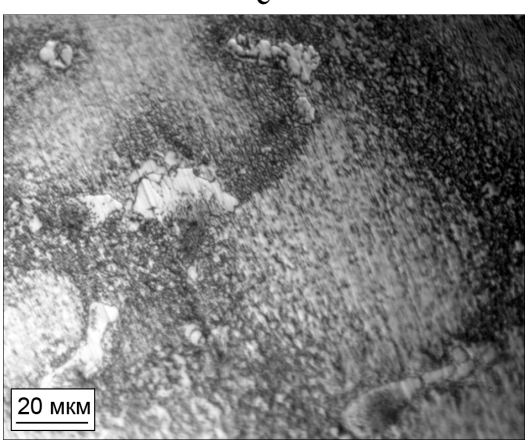

f

Fig. 2. Microstructure of the ZhS32-VI alloy in the longitudinal (a-c) and transverse (d-f) directions

During the directional crystallization, a dendritic-cellular structure was formed. The axes of the first order (primary axes) of dendritic cells with a length of $40-60 \mu \mathrm{m}$ are oriented along the longitudinal axis of the sample, which coincides with the direction of crystallization. The axes of the second order (secondary axes) of dendritic cells are underdeveloped. Accordingly, microstructure images of the sample in the transverse direction display the cross-section of the columnar dendrites in the form of "Maltese crosses" [16], formed by the secondary axes of the dendrites (Fig. 2, $d, e$ ). According to the literature [17], such an oriented dendritic structure provides high operational properties, in particular long-term heat resistance. As a rule, eutectic colonies of nonequilibrium $\left(\gamma+\gamma^{\prime}\right)$ phases as well as individual particles of the carbide phase of polyhedral morphology, which are identified as MC carbides based on $\mathrm{Ta}(\mathrm{Nb}, \mathrm{W}) \mathrm{C}$, are located in the interdendritic layers. The size of the irregular shaped eutectic colonies reaches several tens of micrometers.

The microstructure images of a sample of the ZhS6K-VI alloy also display a dendritic structure, but in contrast to the ZhS32-VI alloy, this structure is characterized by almost uniformly developed axes of 


\section{Microstructure and Microhardness of Nickel-base Heat-resistant Alloys Obtained by ...}

both the first and second orders (Fig. 3, $a, d$ ). Due to the lower crystallization rate during the production of the ZhS6K-VI alloy, a coarse dendritic structure with an average size of equiaxed dendritic crystallites of $100-150 \mu \mathrm{m}$ is formed (Fig. 3, a). The dendrites are randomly oriented in the volume of the sample.

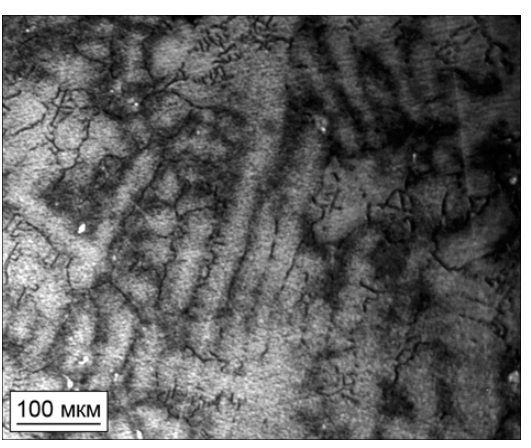

a

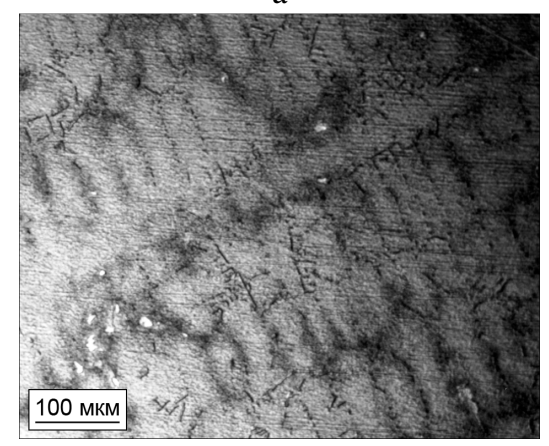

d

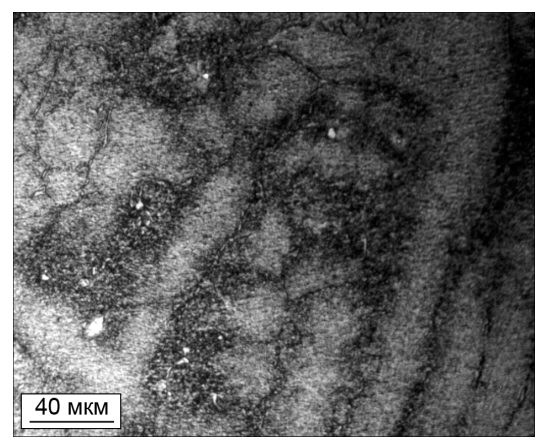

b

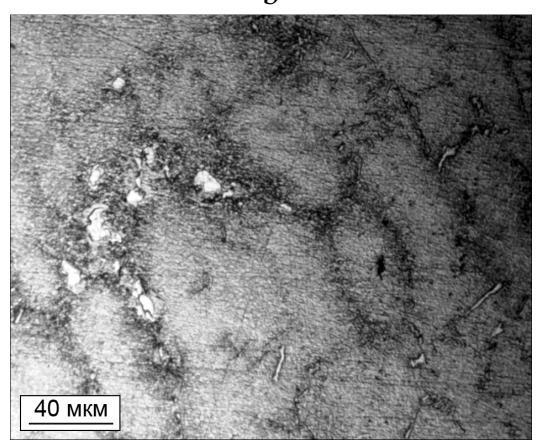

$\mathrm{e}$

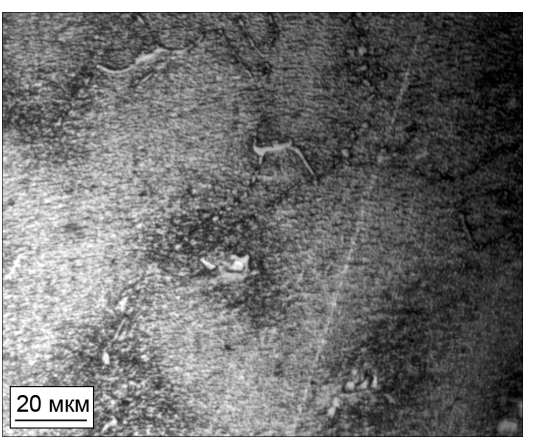

c

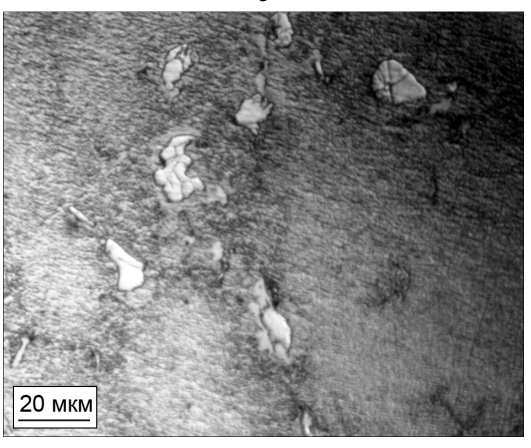

$\mathrm{f}$

Fig. 3. Microstructure of the ZhS6K-VI alloy in the longitudinal $(a-c)$ and transverse $(d-f)$ directions

Dendrites are formed from a nickel-based $\gamma$-solid solution, with distributed in it ultrafine particles of the reinforcing $\gamma^{\prime}$-phase. Eutectic $\left(\gamma+\gamma^{\prime}\right)$ colonies of irregular shape are located in the interdendritic layers. Their size (from several to $10 \mu \mathrm{m}$ ) and volume percentage in the structure of the alloy are much smaller as compared to the $\mathrm{ZhS} 32-\mathrm{VI}$ alloy.

Thus, the revealed differences in the structure of the investigated alloys are naturally consistent with the conditions of equilibrium and high-speed directional crystallizations.

\section{Conclusions}

A significant difference in the parameters of the dendritic microstructure of the investigated nickelbase heat-resistant alloys has been revealed. In particular, the $\mathrm{ZhS32-VI}$ alloy after directional crystallization is characterized by a columnar dendritic microstructure of the cellular type, in which the axes of the first order are oriented in the direction of crystallization, and the axes of the second order are underdeveloped. Coarse, relatively equiaxed dendritic crystallites with evenly developed primary and secondary axes crystallize in the ZhS6K-VI alloy during equilibrium crystallization. Colonies of $\left(\gamma+\gamma^{\prime}\right)$ eutectic, larger in size and number as compared to the alloy ZhS32-VI, are located in the interdendritic layers of the alloy. Despite the differences in structure, the microhardness of the alloys differs slightly. Nevertheless, a slightly lower anisotropy of microhardness (2.8\%) measured in transverse and longitudinal sections was observed in the ZhS6K-VI alloy as compared to the anisotropy (5.1\%) in the ZhS32-VI alloy. Since the elements of gas turbine engines operate in a complex stress state, even a slight increase in the anisotropy of mechanical properties can significantly affect their operational life, especially in the case of crack like microdefects.

\section{Acknowledgements}

This research was supported by the Ministry of Education and Science of Ukraine under the project number 0119U002248 "Improvement of reliability and forecasting of the safe operational life of elements for turbine engines of aviation engineering". We also express our sincere gratitude to Pavlo Lyutyy for performing X-ray analysis and interpretation of the obtained results. 


\section{References}

[1] Yu. Molkov, et al., "Experimental determination of critical strain energy density of ductile materials", Ukrainian Journal of Mechanical Engineering and Materials Science, vol. 5, no. 1, pp. 39-44, 2019.

[2] Z. A. Duriagina, et al., Splavy z osoblyvymy vlastyvostiamy [Alloys with special properties]. Lviv, Ukraine: Lviv Polytechnic National University Publ., 2007. [in Ukrainian].

[3] S. V. Hajduk, and C. B. Bielikov, Naukovi osnovy proektuvannia lyvarnykh zharomitsnykh nikelevykh splaviv z neobkhidnym kompleksom sluzhbovykh vlastyvostei [Scientific bases of designing of foundry heat-resistant nickel alloys with a necessary complex of service properties]. Zaporizhzhia, Ukraine: Zaporizhzhia Polytechnic National University Publ., 2017. [in Ukrainian].

[4] S. T. Kishkin, Liteinyie zharoprochnyie splavy na nikielievoi osnovie [Nickel-based heat-resistant foundry alloys]. Moscow, Russia: Mashinostroenie Publ., 1987. [in Russian].

[5] R.M. Nazarkin, et al., "Strukturno-fazovyie kharaktieristiki splava ZhS32-VI, poluchienoho mietodami napravlennoi kristallizatsyi, hranulnoi mietallurhii i sieliektivnoho laziernoho splavleniia" ["Structural and phase characteristics of the ZhS32-VI alloy obtained by methods of directed crystallization, granular metallurgy and selective laser fusion"], Trudy VIAM [Proceedings of VIAM], vol. 50, no. 2, pp. 11-17, 2017. [in Russian].

[6] A.V. Zavodov, et al., "Mikrostruktura i fazovyi sostav zharoprochnoho splava ZhS32 poslie sieliektivnoho laziernoho splavlieniia, vakuumnoi tiermicheskoi obrabotki i horiacheho izostaticheskoho pressovaniia" ["Microstructure and phase composition of $\mathrm{ZhS32}$ superalloy after selective laser melting, vacuum heat treatment and hot isostatic pressing"]. Pisma o matierialakh [Letters on Materials], vol. 7 (2), pp. 111-116, 2017. [in Russian].

[7] N. Ye. Kalinina, et al. "Mekhanichieskiie i korrozionnyie svoistva mnohokomponientnykh splavov, modifitsyrovannykh dispersnymi kompozitsyiami" ["Mechanical and corrosion properties of multicomponent alloys, modified by disperse compositions"], Stroitielstvo, matierialoviedieniie, mashynostroieniie [Construction, materials science, mechanical engineering], vol. 104., pp. 146-150, 2018. [in Russian].

[8] N. A. Lysenko, V. V. Klochykhin, and V. V. Naumyk, "Struktura i svoistva pustotelykh otlivok lopatok turbiny iz nikielievykh splavov poslie horiachieho izostatichieskoho prossovaniia ["Structure and properties of hollow castings of turbine blades from nickel alloys after hot isostatic pressing"], Aviatsyonno-kosmycheskaia tekhnika $i$ tekhnolohiia [Aerospace engineering and technology], no. 10 (127), pp. 19-27, 2015. [in Russian].

[9] A. H. Andriienko, S. V. Gayduk, and V. V. Kononov, "Mekhanichieskiie svoistva i tiekhnolohichieskiie osobiennosti poluchieniia detalei HTU s napravliennoi (mono) strukturoi iz zharoprochnoho korrozionnostoikoho nikielievoho splava" ["Mechanical properties and technological procedure features in manufacture of gas turbine parts with directed (mono) crystallization made of corrosion-resistant nickel-base superalloy"], Novi materialy $i$ tekhnolohii $v$ metalurhii ta mashynobuduvanni [New materials and technologies in metallurgy and mechanical engineering], no. 2, pp. 81-86, 2012. [in Russian].

[10] Elvatech. Advanced XRF equipment and solutions, 2019. [Online]. Available: https://elvatech.com/. Accessed on: December 30, 2019.

[11] L. G. Akselrud, Yu. N. Grin, and P. Yu. Zavalij, "CSD-universal program package for single crystal or powder structure data treatment", in Collected Abstracts of $12^{\text {th }}$ European Crystallographic Meeting, Moscow, Russia, August 20-29, 1989, p. 155.

[12] Available Software for Powder Diffraction Indexing including a Literature Search List, 2019. [Online]. Available: http://www.ccp14.ac.uk/solution/indexing/. Accessed on: December 30, 2019.

[13] J. Rodriguez-Carvajal, "Recent developments of the program FULLPROF, in Ccommission on Powder Diffraction (IUCr)", Newsletter, vol. 26, pp. 12-19, 2001.

[14] Materialy metalevi. Vyznachennia tverdosti za Vikersom [Metallic materials. Determination of Vickers hardness], DSTU ISO 6507-1:2007, 2010. [in Ukrainian].

[15] V. V. Azhazha, et al., "Rol teplofizicheskikh uslovii v protsessie formirovaniia struktury pri napravliennoi krystallizatsyi zharoprochnykh splavov na nikielievoi osnovie" ["Role of thermal and physical conditions during shaping structure at a directional crystallization of heat resisting alloys on nickel base"], Voprosy atomnoi nauki $i$ tekhniki [Issues of nuclear science and technology], no. 6, pp. 128-135, 2004. [in Russian].

[16] E. N. Kablov, E. E. Hierasimov, and A. V. Dubrovskii, "Tekhnolohichieskiie aspekty upravleniia strukturoi zharoprochnykh splavov pri napravliennoi kristallizatsyi" ["Technological aspects of control of structure of heat-resistant alloys at the directed crystallization"], Lytieinoie proizvodstvo [Foundry production], no. 4, pp. 11-25, 1994. [in Russian].

[17] V. V. Azhazha, et al., "Pierspiektivnyie napravlieniia v sovershenstvovanii struktury monokristallichieskykh lopatok hazoturbinnykh dvihatieliei" ["Promising directions in improving the structure of single-crystal blades of gas turbine engines"], Matierialoviedieniie [Materials science], no. 11, pp. 8-19, 2006. [in Russian]. 